\title{
RADIOIMMUNOASSAY OF ANABOLIC STEROIDS: AN EVALUATION OF THREE ANTISERA FOR THE DETECTION OF ANABOLIC STEROIDS IN BIOLOGICAL FLUIDS
}

\author{
Robert DUGAL, Ph.D., Claire DUPUIS, Ph.D. and Michel J. BERTRAND, Ph.D. \\ Centre de Recherches en Sciences de la Santé, \\ Institut National de la Recherche Scientifique, \\ Centre Hospitalier Louis-H. Lafontaine, \\ Montréal, Québec, Canada
}

\begin{abstract}
Recently developped radioimmunoassays (RIA) for the analysis of anabolic steroids and their metabolites in biological fluids were tested for cross-reactivity with other types of steroids. Results show that the degree of desirable cross-reactivity within the two classes of orally active anabolic steroids vary widely and that the antiserum for 19-Nortestosterone (the active principle of intramuscular preparations) has a very high degree of undesirable crossreactivity with components of oral contraceptives. Single and multiple dose studies in human volunteers demonstrate that the detection level and degree of retrospectivity are likewise variable but that the test easily detects most anabolic steroids during treatment. At the present time, the combination of the three antisera for the assay of a sample appears to be a relatively rapid and economic method for screening large numbers of samples in situations where doping control of anabolic steroids is required. The importance of utilizing physico-chemical means for identification of RIA potential positives is emphasized.
\end{abstract}

\section{INTRODUCTION}

Anabolic steroids are chemical and functional relatives of the male sex hormones or androgenic hormones. One of their most remarkable effects is to promote a rapid increase in height and development of the skeletal musculature which, with thickening of the skeleton, contributes to a rapid increase in body weight. This is called the anabolic effect. Several related steroids have been synthesized in an attempt to separate the anabolic properties from the androgenic activity of testosterone so as to obtain compounds which might promote body growth without having masculinizing effects. A complete dissociation of these two effects has, however, yet to be achieved. In spite of all the dangers associated with their use, these compounds have found a wide and uncontrolled application in sports.

It appears that the major doping problem at the present time is the abuse of anabolic steroids. Until 1974 , no method was available that was sensitive enough for the routine detection of anabolic steroids and their metabolites in biological fluids, thus preventing their inclusion in lists of drugs banned by the major international sports organizations and their control at international competitions. Certain anabolic steroids became detectable with the introduction of a radioimmunoassay
(Sumner, 1974: Brooks et al, 1975) and identification procedures for a limited number of them have also been described (Ward et al: 1975).

Following these and other developments, the Inter national Olympic Committee banned the use of anabolic steroids in sports competitions and the major international sports federations followed suit. A symposium held in London in February 1975 prompted the technical commission of F.I.M.S. (International Federation of Sports Medecine) to condemn the prescription of anabolic steroids by physicians to healthy persons participating in sports and to recommend that methods of control be implemented. The first large-scale systematic control of anabolic steroids at a major international event was conducted in this laboratory at the Montreal Olympic Games.

The purposes of the present paper are: To report studies concerning the degree of cross-reaction, with other types of steroids, of three antisera with specificity directed at structural features typical of anabolic steroids; to examine the suitability of the radioimmunoassay for the detection of anabolic steroids and their metabolites in biological fluids; and to determine the degree of retrospectivity of the method after administration of normal pharmacological doses to man.

Requests for reprints to: Dr. Robert Dugal, I.N.R.S.-Santé, L.-H. Lafontaine Hospital, 7401 Hochelaga, Montréal, P.Q. H1N3M5, Canada. 


\section{EXPERIMENTAL}

\section{Sample preparation and assay}

The method described by Brooks et al (1975) was used with minor modifications and is summarized here for convenience. $0.5 \mathrm{ml}$ of unbuffered urine is extracted once with $2.5 \mathrm{ml}$ of freshly redistilled methylene chloride. The organic layer is washed once with $\mathrm{NaOH}$ $0.1 \mathrm{~N}$ and three times with distilled water. The washed organic extract is taken to dryness in a Vortex Evaporator (Buchler) and acetylated overnight with acetic anhydride in pyridine. After acetylation, $2 \mathrm{ml}$ of methanol are added to the tube, and the solvent and excess reagents are dried down. The extract is finally taken up in $2.5 \mathrm{ml}$ of assay buffer. Each determination is the average of triplicate $0.1 \mathrm{ml}$ aliquots.

The radioimmunoassay for the 17- $\alpha$-ethyl and 17- $\alpha$-methyl anabolic steroids have similarly been described by Brooks et al (1975). The method involves the following successive steps: coating of antibodies onto plastic tubes, pre-incubation of sample or standards in assay buffer, incubation with the label solution and counting the tubes in a gamma ray spectrometer.

For the assays, the 17- $\alpha$-methyltestosterone (for 17- $\alpha$-methyl anabolic steroids) and Norethandrolone (for $17-\alpha$-ethyl anabolic steroids) antisera were diluted according to titre requirements $11: 25,000$ and $1: 20,000$ respectively). The radioimmunoassay for 19-Nortestosterone is essentially the same, but as is the case with the 17- $\alpha$-ethyl anabolic steroid test, the acetylation step is eliminated. The antiserum $(1: 10,000)$ was prepared with 19-Nortestosterone-17-HSA and the label was 19-Nortestosterone-17-125 $\mathrm{I}$. Anabolic steroids investigated in this study are listed in TABLE I.

\section{Standard curves}

Standard curves were constructed by plotting on semi-logarithmic paper the number of counts obtained from standard tubes (B) expressed as a relative percentage of the number of counts in the zero tube $\left(B_{0}\right)$ against the amount of standard (pg/tube). The amount of anabolic steroid in unknown samples was read from this standard curve. Because the steroids used as standards are Methanedienone, Norethandrolone and 19-Nortestosterone respectively, all values obtained for unknown samples are expressed in weight equivalents of the respective standard.

\section{Specificity studies}

The specificity of each antiserum was tested by crossreaction studies with various anabolic and non-anabolic steroids likely to be found in the urine samples of athletes. The percent cross-reaction was calculated by plotting dose-response curves of each steroid titrated against Methanedienone, Norethandrolone or 19-Nor-

\section{TABLE I}

\section{Anabolic Steroids Investigated in this Study}

Methyltestosterone

Fluoxymesterone

Methanedienone

Oxandrolone

Oxymetholone

Stanozolol

Methylandrostenediol

Clostebol

Mestanolone

19-Nortestosterone

Ethylestrenol

Norethandrolone
(17- $\beta$-hydroxy-17- $\alpha$-methyl-4-androsten-3-one)

(9- $\alpha$-fluoro-11- $\beta$-17- $\beta$-dihydroxy-17- $\alpha$-methyl-4-androsten-3-one)

(17- $\beta$-hydroxy-17-methylandrosta-1,4-dien-3-one)

(17- $\beta$-hydroxy-17-methy $-2-0 \times a-5-\alpha$-androstan-3-one)

(17- $\beta$-hydroxy-2-(hydroxymethylene)-17-methyl-5- $\alpha$-androstan-3-one)

(17- $\beta$-hydroxy-17-methylandrostano [3,2-c] pyrazol-1-ol)

(17- $\alpha$-methyl-5-androstene-3- $\beta-17-\beta$-diol)

(4-chloro-17- $\beta$-hydroxyandrost-4-en-3-one)

(17- $\beta$-hydroxy-17-methyl-5- $\alpha$-androstan-3-one)

(17- $\beta$-hydroxy-19-norandrost-4-en-3-one)

(17- $\alpha$-ethyl-17-hydroxy-19-norandrost-4-en-3-one)

(17-a-ethyl-17-hydroxy-19-norandrost-4-en-3-one) 
testosterone according to the method of Abraham (1968). The reactivity of each of the three standards was taken as $100 \%$.

\section{Human studies}

In order to test the suitability and retrospectivity of each assay for the detection of anabolic steroids and/or their metabolites in urine, single and multiple-dose urinary excretion studies were performed in normal and healthy male volunteers using minimum recommended therapeutic doses of several commonly used and commercially available anabolic steroids. For the orallyactive anabolic steroids, extemporaneously prepared capsules of the powdered material were administered orally with $200 \mathrm{ml}$ of water. Volunteers were requested to collect daily random urine samples of about $50 \mathrm{ml}$ in pre-labelled bottles for seven days. The following products and doses were given in single-dose experiments: Methanedienone, $50 \mathrm{mg}$; 17-a-methyltestosterone, 50 $\mathrm{mg}$; Methylandrostenediol, $50 \mathrm{mg}$; Stanozolol, $20 \mathrm{mg}$; Oxandrolone, $20 \mathrm{mg}$; Oxymetholone, $50 \mathrm{mg}$; Clostebol, $30 \mathrm{mg}$; Mestanolone, $50 \mathrm{mg}$; Ethylestrenol, $20 \mathrm{mg}$; Norethandrolone, $50 \mathrm{mg}$. One volunteer received a single intramuscular dose $(50 \mathrm{mg})$ of 19-Nortestosterone phenylproprionate (Durabolin, Organon).
Commercially available tablets (or capsules) of the following anabolic steroids were administered at normal pharmacological doses for seven days according to the following schedule: Methanedienone, $5 \mathrm{mg}$ twice daily; 17- $\alpha$-methyltestosterone, $10 \mathrm{mg}$ twice daily; Stanozolol, $2 \mathrm{mg}$ three times a day; Fluoxymesterone, $5 \mathrm{mg}$ twice daily; Oxymetholone, $5 \mathrm{mg}$ twice daily; Norethandrolone, $10 \mathrm{mg}$ twice daily. Random urine samples of about $50 \mathrm{ml}$ were collected daily for the seven days of drug administration and for the following week. All samples were deep-frozen at $-20^{\circ} \mathrm{C}$ until analysis. Urine samples were analyzed with the antiserum and label corresponding to the drug that had been administered. All results were confirmed by $\mathrm{GC} / \mathrm{MS} / \mathrm{COM}$ (to be reported elsewhere).

\section{Mass screening of unknown urine samples}

More than 260 samples collected from athletes in the week prior to and during the Montreal Olympic Games were analyzed using the three antisera simultaneously. The flow diagram of the method is shown in Figure 1. The acetylation step was subsequently bypassed for negative samples in order to determine whether the acetylation process could be eliminated, thus shortening the time of the assay.

\section{ANABOLIC STEROID RADIO-IMMUNOASSAY} EXTRACTION AND ASSAY FLOW DIAGRAM
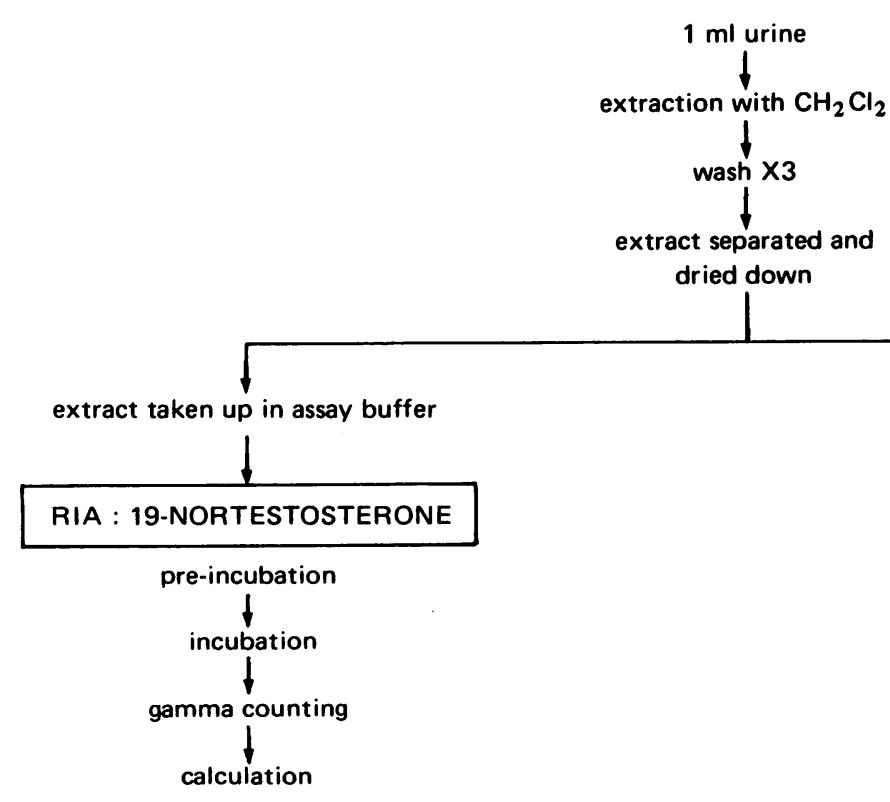

dried down 


\section{RESULTS AND DISCUSSION}

The principle underlying the utilisation of two of the three presently studied radioimmunoassays was to direct the specificity of the antiserum at distinctive structural features of orally active anabolic steroids, namely the $17-\alpha$-methyl and 17- $\alpha$-ethyl groups of the $D$ ring of the basic steroid nucleus. Theoretically, then, it would be desirable that all 17- $\alpha$-methyl derivatives, for example, cross-react to approximately the same extent with the anti-17- $\alpha$-methyltestosterone-3-HSA serum. Simultaneously, anabolic or other steroids not belonging to this category should cross-react to a minimum and preferably not at all. Inspection of Table II reveals that the 17- $\alpha$-methyl anabolic steroids cross-react to very different degrees. As shown, the cross-reactivity of $17-\alpha-$ ethyl derivatives, 19-Nortestosterone and some widely used anti-inflammatory steroids is, for all intents and purposes, negligible. But there is a significant and undesirable degree of cross-reactivity with Norethindrone and Norgestrel which are present in many oral contraceptive preparations. It is further noted that the undesirable cross-reactivity of these two compounds is higher than the desirable but very low reactivity of three $17-\alpha$-methyl anabolic steroids.

\section{TABLE \|}

Relative Cross-Reactivity of Various Steroids with 17- $\alpha$-Methyltestosterone Antiserum

Steroid

Cross-

Reactivity

$(\%)$ *

Methanedienone

100

17- $\alpha$-methyl testosterone

169.7

Clostebol

76.9

Fluoxymesterone

Mestanolone

Oxandrolone

Stanozolol

34.5

20.0

3.6

Oxymetholone

1.1

Methylandrostenediol

$<0.7$

Norethandrolone

$<0.7$

Ethylestrenol

19-Nortestosterone

$<0.7$

Testosterone

Testosterone acetate

Norethindrone

Norgestrel

Prednisone

Prednisolone

Hydrocortisone

Fluprednosolone
Table III shows that Ethylestrenol, a 17- $\alpha$-ethyl anabolic steroid, cross-reacts to the extent of only $28 \%$ with the Norethandrolone antiserum. Norethindrone has an undesirable reactivity of $6.6 \%$. Table IV shows that the 19-Nortestosterone antiserum cross-reacts with Norethandrolone but does not with Ethylestrenol $(<1 \%)$. This is rather unexpected since Norethandrolone differs from Ethylestrenol by a single structural feature, a keto group in the 3-position, and the specificity of the antiserum is directed at the absence of the methyl group in the 19-position, a feature which both compounds share. It is also important to note that Norgestrel and Norethindrone cross-react very significantly, indicating that false positives may possibly be obtained from female athletes using oral contraceptives. This antiserum therefore lacks specificity and cannot be used in lieu of the $17-\alpha$-ethyl antiserum for screening purposes because its reactivity to Ethylestrenol is negligible.

\section{TABLE III}

\section{Relative Cross-Reactivity of Various Steroids with Norethandrolone Antiserum}

Steroid

Cross-
Reactivity

$(\%) *$

Norethandrolone

100

Ethylestrenol

28

Methanedienone

0.6

17- $\alpha$-methyltestosterone

3.7

Fluoxymesterone

$<0.4$

19-Nortestosterone

$<0.4$

Testosterone

$<0.4$

Norethindrone

6.6

Norgestrel

$<0.4$ 
The simultaneous use of both the Norethandrolone and 19-Nortestosterone antisera may, on the other hand, yield useful information. A positive result with the 19-Nortestosterone test for a male urine would indicate the presence of either 19-Nortestosterone or Norethandrolone. By simultaneously using the 17- $\alpha$-ethyl antiserum, it would appear possible to obtain a preliminary identification of the anabolic present in the sample. Thus a sample positive to the 17- $\alpha$-ethyltestosterone assay would contain 19-Nortestosterone, while a sample positive to both antisera would contain Norethandrolone. This may serve as a useful guide in pursuing the identification analysis with physical chemical means such as mass spectrometry.

Figures 2, 3 and 4 show typical dose-response curves for the standards used for each assay, namely Methanedienone (fig. 2), Norethandrolone (fig. 3) and 19-Nortestosterone (Fig. 4). Standard curves for some other anabolic steroids have been included to illustrate their different degree of response to each antiserum. The percent cross-reactivity listed in Tables II, III and IV were calculated from such plots with all substances of interest according to the method of Abraham (1968).

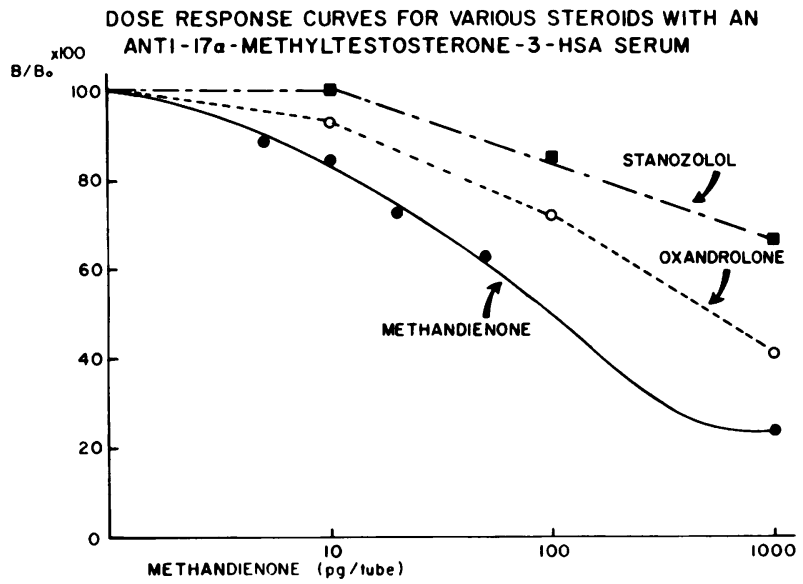

Fig. 2: Calibration curves for Methanedienone and two 17- $\alpha$-methyl anabolic steroids showing the different response of analog derivatives.

The in vitro results reported above were confirmed by studies in volunteers. These are summarized in Table $V$ (single-dose studies) and Table VI (multiple-dose studies) where each sample was analyzed with the corresponding antiserum. Results show that after a single normal dose, Methanedienone, Oxandrolone, Oxymetholone, Norethandrolone and 19-Nortestosterone can be detected from two to four days after administration. Methyltestosterone, Stanozolol, Methylandrostenediol, Clostebol and Ethylestrenol values are, however, barely dis-

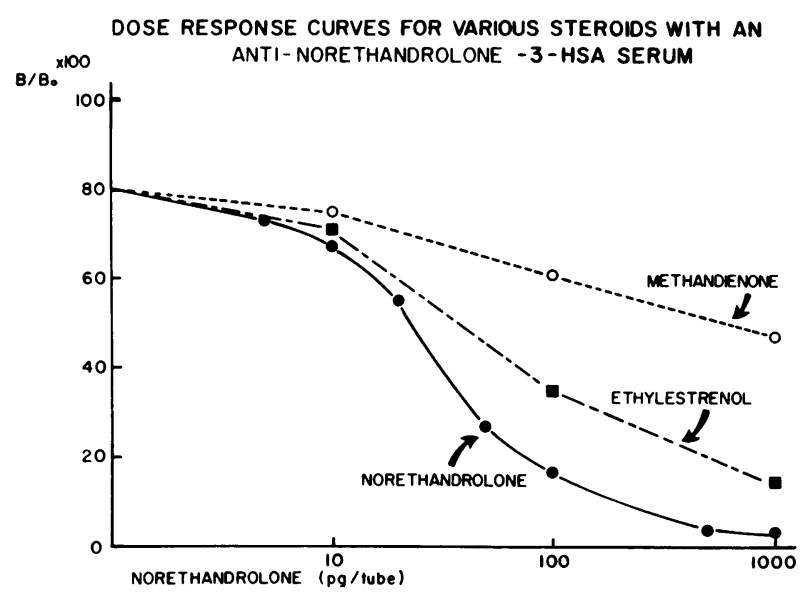

Fig. 3: Calibration curves for two 17- $\alpha$-ethyl anabolic steroids illustrating some degree of cross-reactivity with a 17- $\alpha$-methyl anabolic steroid (Methanedienone).

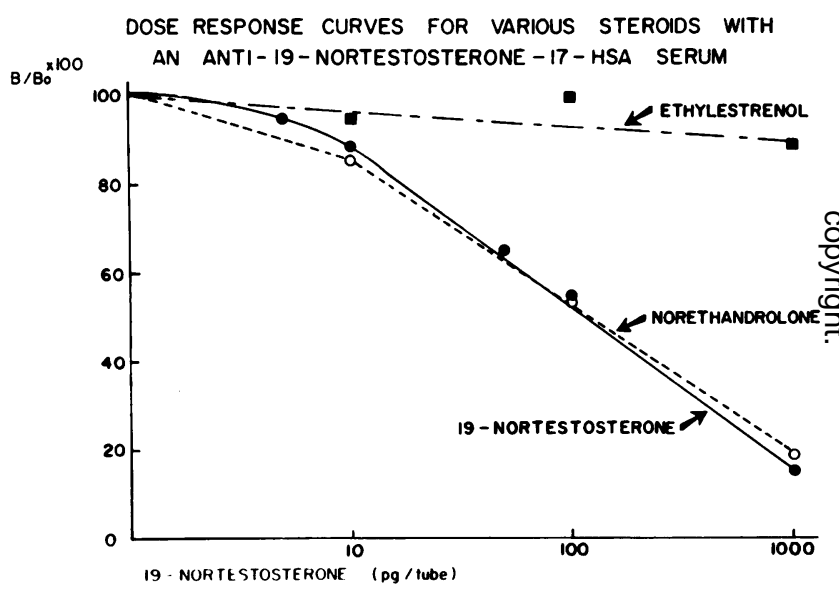

Fig. 4: Calibration curves for 19-Nortestosterone showing the cross reactivity of Norethandrolone and the virtual absence of cross-reactivity of Ethylesteronol.

tinguishable from blank urine values. The blank values were chosen as $2 \mathrm{ng} / \mathrm{ml}$ for Methanedienone, $0.5 \mathrm{ng} / \mathrm{ml}$ for Norethandrolone and $2.5 \mathrm{ng} / \mathrm{ml}$ for 19-Nortestosterone as determined in a large number of drug-free urine samples obtained from normal volunteers.

The results of multiple-dose studies are shown in Table VI. These indicate that most anabolic steroids, with the notable exception of Stanozolol, may be easily and quantitatively detected during treatment. The degree of retrospectivity is however extremely variable after administration of normal doses. Given the very high dosages that athletes are said to use, it is probable that these compounds may be detected for a much longer time after treatment interruption. 
TABLE V

Single-dose Human Studies with Anabolic Steroids

Anabolic Steroid

[Concentrations expressed in weight equivalents of marker ( $\mathrm{ng} / \mathrm{ml}$ of urine)]

\begin{tabular}{|c|c|c|c|c|c|}
\hline Day & $\begin{array}{l}\text { Methanedienone } \\
50 \mathrm{mg} \text { p.o. }\end{array}$ & $\begin{array}{l}\text { Methyltestosterone } \\
50 \mathrm{mg} \text { p.o. }\end{array}$ & $\begin{array}{l}\text { Stanozolol } \\
20 \mathrm{mg} \text { p.o. }\end{array}$ & $\begin{array}{l}\text { Methylandrostenediol } \\
50 \mathrm{mg} \text { p.o. }\end{array}$ & $\begin{array}{l}\text { Oxandr } \\
20 \mathrm{mg}\end{array}$ \\
\hline $0^{a}$ & 1.6 & 0.9 & 0.1 & 0 & 0.7 \\
\hline Poolb & $>50$ & 1.0 & 0.2 & 0.3 & 4.8 \\
\hline 3 & 4.4 & 0.7 & $*$ & N.D. & 7.8 \\
\hline 4 & 2.6 & N.D. & 0.2 & N.D. & 0.8 \\
\hline 5 & 1.9 & N.D. & 0.2 & N.D. & 1.2 \\
\hline 6 & N.D. & $*$ & 0.2 & * & N.D. \\
\hline 7 & N.D. & $*$ & $*$ & $*$ & $*$ \\
\hline Day & $\begin{array}{l}\text { Oxymetholone } \\
50 \mathrm{mg} \text { p.o. }\end{array}$ & $\begin{array}{l}\text { Clostebol } \\
30 \mathrm{mg} \text { p.o. }\end{array}$ & $\begin{array}{l}\text { Norethandrolone } \\
50 \mathrm{mg} \text { p.o. }\end{array}$ & $\begin{array}{l}\text { Ethylestrenol } \\
20 \mathrm{mg} \text { p.o. }\end{array}$ & $\begin{array}{l}\text { 19-Nor } \\
50 \mathrm{mg} i\end{array}$ \\
\hline $0^{a}$ & 0.2 & 0 & 0.3 & 0.3 & 0 \\
\hline Poolb & 1.3 & 0.4 & $>50$ & 0.5 & 0.5 \\
\hline 3 & 0.5 & 0.5 & 1.7 & 0.5 & $>50$ \\
\hline 4 & 0.9 & 0.3 & 0.5 & N.D. & $>50$ \\
\hline 5 & 0.6 & N.D. & 0.3 & N.D. & 1.4 \\
\hline 6 & 0.6 & $*$ & N.D. & N.D. & 2.0 \\
\hline 7 & * & * & * & $*$ & \\
\hline
\end{tabular}

a Blank urine readings

b Pool: day 1 and day 2 together

* Not determined

N.D. Not detectable

TABLE VI

Multiple-dose Human Studies with Anabolic Steroids

\begin{tabular}{|c|c|c|c|c|c|c|}
\hline \multirow[b]{2}{*}{ Day } & \multicolumn{6}{|c|}{ Anabolic Steroid } \\
\hline & $\begin{array}{l}\text { Methandedienone }{ }^{a} \\
5 \mathrm{mg} \text { b.i.d. }\end{array}$ & $\begin{array}{l}\text { 17-Methyltestosterone }{ }^{a} \\
10 \mathrm{mg} \text { b.i.d. }\end{array}$ & $\begin{array}{l}\text { Stanozolol } \\
2 \mathrm{mg} \text { t.i.d. }\end{array}$ & $\begin{array}{l}\text { Fluoxymesterone }{ }^{a} \\
5 \mathrm{mg} \text { b.i.d. }\end{array}$ & $\begin{array}{l}\text { Oxymetholone }{ }^{a} \\
5 \text { mg b.i.d. }\end{array}$ & $\begin{array}{l}\text { Noretha } \\
10 \mathrm{mg} \mathrm{b}\end{array}$ \\
\hline $0^{c}$ & 0.3 & 0.7 & 0.3 & 0.2 & 1.3 & 0.4 \\
\hline 1 & $>50$ & 1.3 & N.D. & 3.5 & 3.8 & $>50$ \\
\hline 2 & $>50$ & 2.0 & N.D. & 2.7 & $>50$ & 28 \\
\hline 3 & $>50$ & 5.2 & N.D. & 5.2 & $>50$ & $>50$ \\
\hline 4 & $>50$ & 5.0 & N.D. & 2.2 & 4.3 & 10 \\
\hline 5 & 17.5 & 2.8 & N.D. & 1.2 & 1.3 & 27 \\
\hline 6 & 5.4 & 10.0 & N.D. & 4.7 & 5.5 & $>50$ \\
\hline 7 & 5.4 & 1.9 & N.D. & 2.8 & 5.1 & 6 \\
\hline 8 & 0.8 & 1.4 & N.D. & 1.9 & 3.2 & 0.7 \\
\hline 9 & $*$ & N.D. & N.D. & 0.3 & 2.6 & N.D. \\
\hline 10 & N.D. & N.D. & N.D. & N.D. & 2.8 & N.D. \\
\hline 11 & N.D. & N.D. & * & N.D. & 1.7 & N.D. \\
\hline 12 & N.D. & N.D. & * & N.D. & 2.9 & N.D. \\
\hline 13 & N.D. & N.D. & * & N.D. & 5.1 & N.D. \\
\hline 14 & * & N.D. & $*$ & N.D. & 2.8 & N.D. \\
\hline
\end{tabular}

\footnotetext{
a All values are expressed in $\mathrm{ng} / \mathrm{ml}$, in "equivalents" of methanedienone

b All values are expressed in $\mathrm{ng} / \mathrm{ml}$, in "equivalents" of norethandrolone

c Blank urine readings

* Not determined

N.D. Not detectable
} 
The degree of retrospectivity could, in addition, be increased by extraction of larger volumes or by hydrolyzing samples before extraction. Results from this laboratory (Bertrand, M., Massé, R. and Dugal, R. to be published) using chemical ionization gas chromatography/mass spectrometry have also shown that a more effective detection of most anabolic steroids may be made with this technique. The principal disadvantage however of using GC/MS for handling a large number of samples is the length of time required for each analysis and the relatively high cost of using sophisticated equipment. Thus, the three radioimmunoassays used in parallel constitute, at the present time, a relatively rapid and economical method for the detection of most anabolic steroids. But caution should be exercized in interpreting results because the method has some very serious limitations and should therefore be considered strictly as a preliminary screening technique.

As an illustration of results obtained with actual samples from athletes, Table VII shows the RIA values (with the three antisera) for those samples which were subsequently identified by gas-chromatography/mass spectrometry at the Montreal Olympic Games. Assuming that these athletes were taking only one anabolic steroid (and no evidence to the contrary could be found), it appears that the cross-reactivity between antisera becomes important when concentrations resulting from large doses of anabolic steroids are found in urine. This may however be considered as an advantage since positive results with two or three antisera may serve as strong preliminary evidence of the presence of an anabolic steroid in the sample. It has however the disadvantage of not being a very useful indication as to the exact class of compound present in the sample.

The length of time required for the assay of $17-\alpha-$ methyl anabolic steroids is, at the present time, about 2 or 3 days depending on working schedules. This represents some disadvantage in situations where results have to be delivered rapidly, as in international competitions. It was found that the elimination of the acetylation step in the sample preparation procedure could contribute considerably to shorten the time of analysis. Negative urine samples obtained from athletes during the Montreal Olympic Games were analyzed simultaneously by the conventional method and by eliminating the acetylation step. Non-acetylated aliquots gave slightly higher response readings than acetylated samples but the responses were always lower than the chosen limit of detection. Moreover, values of non-acetylated samples were not significantly different $(p=0.1)$ from those obtained from acetylated samples (as determined by the paired values $t$-test). Bypassing the acetylation step may introduce some risk of increasing the number of false positives but reduces the analysis time by about $50 \%$. The authors estimate that this risk is acceptable in situations where a large number of samples have to be analyzed in international competitions and where the time constraints imposed on the laboratory are important. It is evidently necessary that gas chromatography/mass spectrometry facilities be available to confirm all RIA results.

\section{ACKNOWLEDGEMENTS}

The authors wish to express their gratitude to Professor R. V. Brooks, St. Thomas Hospital Medical School, London, U.K., for providing generous supplies of the three anabolic steroid radioimmunoassays and for helpful discussions.

TABLE VII

RIA Values for GC/MS Positives 1976 Summer Olympic Games

$\begin{array}{lccc}\begin{array}{l}\text { Laboratory } \\ \text { Code Number }\end{array} & \begin{array}{l}\text { 19-Nortestosterone } \\ \text { Antiserum }\end{array} & \begin{array}{l}\text { 17- } \alpha \text {-Methytestoste;one } \\ \text { Antiserum }\end{array} & \begin{array}{l}\text { Norethandrolone } \\ \text { Antiserum }\end{array} \\ \text { S-135 } & 3.10 & >50 & 0 \\ \text { S-118 } & 0.55 & 5.25 & 0 \\ \text { S-102 } & 0.65 & >50 & 0 \\ \text { S-011 } & 1.20 & >50 & 0 \\ \text { S-184 } & >50 & >50 & 2.50 \\ \text { S-107 } & >50 & >50 & 0 \\ \text { S-177 } & >50 & >50 & 3.20 \\ \text { S-167 } & >50 & >50 & >50\end{array}$




\section{REFERENCES}

Abraham, G. E. 1968. Solid-phase radioimmunoassay of Estradiol-17-ß. J.Clin.Endocrinol.Metab., 29: 866-870.

Brooks, R. V., Firth, R. G. and Sumner, N.A. 1975. Detection of Anabolic Steroids by radioimmunoassay. Brit.J.Sports Med., 9: 89-92.

Sumner, N. A. 1974. Measurement of anabolic steroids by radioimmunoassay. J.Steroid Biochem., 5: 307.

Ward, R. J., Shackleton, C. H. L. and Lawson, A. M. 1975. Gas-chromatographic/mass spectrometric methods for the detection and identification of anabolic steroid drugs. Brit.J. Sports Med., 9: 93-97. 